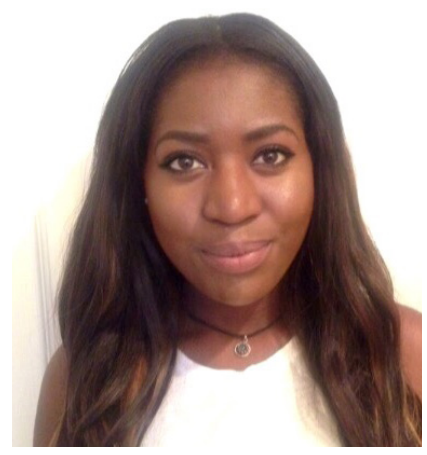

LUISA TEMBO is a third year Political Science major, with a concentration in Global Politics and a minor in Ethics, Public Policy, Science and Technology. She is involved in the ASI Executive Staff (Green Team) and Inter Housing Council (IHC). Her paper was inspired by the portrayal of human societies and the themes of interconnection in the documentary film Samsara (2011). 


\title{
NATIONAL DEVELOPMENT AND INDIGENOUS PEOPLES LAND RIGHTS
}

\section{Luisa Tembo}

\begin{abstract}
As the Western world gradually depletes their own lands, they migrate to developing nations and appropriate their resources. Sub-Saharan Africa is one of the most vulnerable regions in the world due to instability in the region. Globalization has perpetuated a cycle of exploitation that has made us increasingly interdependent on one another for survival. International organizations such as the IMF and the United Nations have attempted to aid indigenous peoples from corporations who take advantage of the overwhelming number of African governments that desperately desire to develop and advance their broken and corrupt nations. However, the structure of these institutions are incredibly duplicitous. In order to achieve sustainable development, there needs to be a fundamental change in the system. ${ }^{1}$ Nonetheless, intervention by these international organizations are vital for indigenous people's protection from corporate greed.
\end{abstract}

${ }^{1}$ John Perkins. Confessions of an Economic Hitman. (New York: Plume, 2005). http://resistir. info/livros/john_perkins_confessions_of_an_economic_hit_man.pdf 


\section{National Development and Indigenous Peoples Land Rights}

In Samsara (2011), there is a scene in a Sub-Saharan African village in Namibia that shows indigenous women from the Himba tribe, wearing very little clothing, lavish ornaments, and body paint made out of a mixture of red ochre and butterfat. They are surrounded by many smiling children who are also minimally clothed. In the background, you can see their huts made out of neatly piled branches and mud. To the average American living in an industrialized modern society, these living conditions may seem severely challenging. Although it may appear that they are living in extreme poverty, the Himba people are living a self-sustaining lifestyle. The following scene was a manmade landscape consisting of a double decker freeway system full of modern automobiles in North America. The drastic differences in lifestyles would lead one to believe that these scenes were taken centuries apart, however; these scenes were happening simultaneously in the 21st century. What historical premises lead to such drastic differences between these two regions? Specifically, how has their symbiotic relationship with nature been affected by their government's national development policies?

The Himba are an indigenous people that lead a semi-nomadic pastoral way of life. They are located in North-West Namibia, in the Kunene region, with a population size ranging from twenty-five to fifty thousand. ${ }^{2}$ Contrary to public misconception, they live in highly functioning, self-sustaining societies. By their standards, the Himba are a wealthy people, who enjoy a rich culture and a satisfying lifestyle. They live in an egalitarian society based on a bilineal family structure, shared ethnicity, and shared linguistics. Although they have no formal system of government or political organization, they have a traditional system of government based on chiefdoms, where head chiefs decide day-to-day matters. ${ }^{3}$ The Himba are considered to be some of the most successful and economically independent subsistent farmers in Africa. Their strategies for food security have proven successful even in times of severe drought. This is important because Namibia has an extremely dry climate that often leads to severe water shortages in

\footnotetext{
${ }^{2}$ Henning Melber. "Re-examining Liberation in Namibia: Political Cultures since Independence.” (Uppsala: Nordic Africa Institute, 2003), 48.

${ }^{3}$ Sidney L. Harring. "God Gave us this Land: The OvaHimba, the proposed Epupa Dam, the independent Namibian state, and law and development in Africa." Georgetown International Environmental Law Review, 14(1) (2001): 35-106, accessed December 2, 2015, http:// search.proquest.com/docview/225506935?accountid=10362.
} 
many parts of the country for often long periods of time. ${ }^{4}$ Pastoralism is common in Himba society as the Himba "economy" is based on cattle trade, with herds averaging 100 per family and reaching at least 500 for some wealthy families. Owning many livestock such as cattle, sheep, and goats, is a sign of affluence. ${ }^{5}$

To understand the complexity of their recent environmental problems, an examination of Namibia's history is necessary. Namibia, like many other SubSaharan African countries, has a long history of colonial rule. It was under German colonial rule from 1883 to 1915. After Germany suffered a loss in WWI, Namibia was under the control of the League of Nations, then the United Nations. Under the mandate, the territory, called South West Africa at the time, was administered by South Africa, who was under British and Dutch rule. $^{6}$ The colonial powers of South Africa institutionalized racism through racially discriminatory apartheid policies that affected the social, political, and economic lives of the black minorities. Governmental attempts at reforming civil society were motivated largely by political and ideological concerns. For example, the creation of an all-white Advisory Council in 1921 to advise the South African-appointed Administrator, the introduction of English and Dutch as official languages, and Roman-Dutch Law as the common law in Namibia, land policy, education policy, as well as the active encouragement of white settlement, were all concentrated efforts in reconfiguring the public sphere in Namibia so as to contain the movement of the majority black population. ${ }^{7}$

The colonizers main goal was to utilize the resources of the colonies for profit. Private ownership of land was highly restricted and incredibly rare; the locals

\footnotetext{
${ }^{4}$ Ibrahima Thomas, and Moses Chakanga, "Role of Planted Forests and Trees Outside Forests in Sustainable Forest Management" FAO Corporate Document Repository, 2001, May 21. http://www.fao.org/docrep/009/j5838e/J5838E10.htm.

${ }^{5}$ Sidney L. Harring. "God Gave us this Land: The OvaHimba, the proposed Epupa Dam, the independent Namibian state, and law and development in Africa." Georgetown International Environmental Law Review, 14(1) (2001): 35-106, accessed December 2, 2015, http:// search.proquest.com/docview/225506935?accountid=10362.

${ }^{6}$ James Anaya. "Report of the Special Rapporteur on the Rights of Indigenous Peoples: The Situation of Indigenous Peoples in Namibia." United Nations Human Rights Council, June 25, 2013, http://www.iwgia.org/iwgia_files_news_files/0921_2013-report-namibia-a-hrc24-41-add1-en.pdf.

7 Ibrahima Thomas, and Moses Chakanga, "Role of Planted Forests and Trees Outside Forests in Sustainable Forest Management" FAO Corporate Document Repository, 2001, May 21. http://www.fao.org/docrep/009/j5838e/J5838E10.htm.
} 
were disposed of their lands and many indigenous people lost their lands as well. The Himba's herds were an economic threat to South African interests. In response the colonial administrators placed restrictions on livestock and cut off opportunities for trade and wage labor. They controlled the border with Angola by forbidding Angolan traders in the territory, and by attempting to stop the Himba and their cattle from freely crossing the border. ${ }^{8}$ The impact of closing these borders was devastating to the Himba because most of their traditional trade routes were no longer available. South Africa's intent was to destroy the Himba pastoral economy in order to force them into signing migrant labor contracts and working in South African mines. ${ }^{9}$ The Portuguese, who had colonized Angola, also restricted the economic activists of the Himba on the Angolan side of the Kunene. With these few exceptions, the Himba lived in relative isolation apart from colonial rule in comparison to other Namibians. As a result, the Himba have been able to preserve their way of life because the Himba deliberately stay distinct from Namibian society. ${ }^{10}$

Desperate for liberation, Namibians petitioned the United Nations against South African rule and a concentrated effort towards independence began. In 1988, South Africa finally agreed to end its administration, and on March 13, 1990, Namibia finally gained its independence. ${ }^{11}$ They established a multiparty constitutional democracy, and became the first African country to incorporate protection of the environment into its constitution. ${ }^{12}$ Today, it still remains one of the few countries in the world who has put such an emphasis on protection of natural resources and habitat conservation in their constitution. The Namibian government was successful in repealing many of their previous colonizers oppressive laws. However, the Namibian constitution states that all

\footnotetext{
${ }^{8}$ Ibid.

${ }^{9}$ Sidney L. Harring. "God Gave us this Land: The OvaHimba, the proposed Epupa Dam, the independent Namibian state, and law and development in Africa." Georgetown International Environmental Law Review, 14(1) (2001): 26, accessed December 2, 2015, http:// search.proquest.com/docview/225506935?accountid=10362.

${ }^{10}$ James Anaya. "Report of the Special Rapporteur on the Rights of Indigenous Peoples: The Situation of Indigenous Peoples in Namibia." United Nations Human Rights Council, June 25, 2013, http://www.iwgia.org/iwgia_files_news_files/0921_2013-report-namibia-a-hrc24-41-add1-en.pdf.

${ }^{11}$ Ibid.

12 “Namibia," World Wildlife Fund. n.d. http://www.worldwildlife.org/places/namibia.
} 
land, water, and natural resources of Namibia belong to the state. ${ }^{13}$ This policy is extremely reflective of their European colonizers way of thought, and further perpetuates inequity in society. There are also no specific rights to indigenous peoples as all traditional communities are considered indigenous to Namibia under its constitution, which completely undermines the necessary regard needed of indigenous minorities as well as their special needs. ${ }^{14}$

Nonetheless, the government does provide assistance to disadvantaged groups in many ways. One of the most substantial programs it passed was its legislation on communal conservancies. Communal conservancies are a legally registered area with clearly defined borders and a constituted management body run by the community for the development of residents and the sustainable use of wildlife and tourism. They are a key development strategy for rural Namibia as they cover $17 \%$ of the country, and approximately one in four rural Namibians now belongs to a registered conservancy.7 The Himba, as well as other indigenous groups in the area are recognized as particularly marginalized by the Namibian government and there are laws and policies particularly devoted to their needs. ${ }^{15}$ Additionally, tourism is a growing industry, contributing to $20 \%$ of the country's GNP, and is used as a lever for economic growth within African conservancies. ${ }^{16}$ One of the country's main concerns is how to sustain the environment while developing ecotourism. However, because the Himba live within communal areas, the tourist industries encourage visiting the indigenous tribes, and sometimes paint an inaccurate depiction of these tribes by using phrases such as "historically disadvantaged people" as a selling point. ${ }^{17}$

The dispute of the Himba people's land and natural resource rights was

\footnotetext{
${ }^{13}$ Henning Melber. "Re-examining Liberation in Namibia: Political Cultures since Independence.” (Uppsala: Nordic Africa Institute, 2003), 48.

${ }^{14}$ Ibid.

${ }^{15}$ James Anaya. "Report of the Special Rapporteur on the Rights of Indigenous Peoples: The Situation of Indigenous Peoples in Namibia." United Nations Human Rights Council, June 25, 2013, http://www.iwgia.org/iwgia_files_news_files/0921_2013-report-namibia-a-hrc24-41-add1-en.pdf.

${ }^{16}$ Anene Ejikeme, Culture and Customs of Namibia. (Westport: Greenwood Publishing Group, 2011), 23.

17 A.P. Davis, "Consequences of 'conservation': A Critical look at Namibian Communal Conservancies," 2011, https://dlc.dlib.indiana.edu/dlc/bitstream/handle/10535/7179/\%20Namibia.pdf?sequence $=1$.
} 
discussed because of the government's desire, as a newly independent country, to develop. In the mid 1990s, the Namibian government wanted to invest in development in order to become a global player capable of writing their own course. The Himba and the government have competing interests when it comes to the use of the Kunene River. The Kunene River is one of three permanently flowing rivers that supports a unique ecosystem in the North-West border of Angola and Namibia. ${ }^{18}$ It is the largest body of water by the Himba people, who get their livelihood from the river. In order to help supply energy to its people, the Angolan and Namibian government proposed a hydropower scheme called the Epupa Dam project. Namibia had an increasing need for power and considered the river as a gift from nature that needed to be utilized to build a hydro-electric power dam. There was a lot of controversy as to whom this dam would benefit most because most of the energy was being distributed to the urban areas, which was less densely populated than the rural areas. ${ }^{19}$ NamPower, Namibia's main energy supplier advocated for the dam as it was importing up around $50 \%$ of its power from South Africa, and wanted to diminish its dependency on foreign powers for energy. ${ }^{20}$ The feasibility study was supported and funded by Norway and Sweden. The project would have two sites: at the Epupa river and the Baynes river. The Namibian government insisted that the dam be built at the Epupa Falls site on the Kunene River instead of the Baynes site because it has greater use value than the Baynes site, regardless of the fact that research showed that the environmental and social costs on the Himba would be much greater. ${ }^{21}$

\footnotetext{
${ }^{18}$ Sidney L. Harring. "God Gave us this Land: The OvaHimba, the proposed Epupa Dam, the independent Namibian state, and law and development in Africa." Georgetown International Environmental Law Review, 14(1) (2001): 35-106, accessed December 2, 2015, http:// search.proquest.com/docview/225506935?accountid=10362.

${ }^{19}$ Andrew Corbett. "A Case Study on the Proposed Epupa Hydropower Dam in Namibia." Prepared for Thematic Review I.2: Dams, indigenous people and vulnerable ethnic minorities, December 1999, http://citeseerx.ist.psu.edu/viewdoc/download?doi=10.1.1.196.5858\&rep=rep1\&type=pdf.

${ }^{20}$ Ibid.

${ }^{21}$ Sidney L. Harring. "God Gave us this Land: The OvaHimba, the proposed Epupa Dam, the independent Namibian state, and law and development in Africa." Georgetown International Environmental Law Review, 14(1) (2001): 26, accessed December 2, 2015, http:// search.proquest.com/docview/225506935?accountid=10362.
} 
The Eupa site is significant because it is utilized by the Himba for survival. ${ }^{22}$ The Himba opposed the proposed dam as the consequences would have been severe. First, there would be a flooding of the heart of their lands with a reservoir, which would result in a loss of biodiversity. Second, there would be a disruption of their lives and culture. Although the Himba are nomadic, some families are well established in some areas. The Epupa site would have flooded 110 permanent dwellings of the Himba, resulting in the displacement of many people. It would also affect the drought strategies of many Himba people, as it is a crucial source of grazing and browsing in dry seasons and in times of drought. ${ }^{23}$ One of the main reasons for opposition towards the dam would be that of culturally-important ancestral graves. The graveyards have a diverse array of functions and significance in Himba society. The Himba believe that their culture will be at risk as the graveyard is far more than just the physical remains of a deceased person; it is the focal point for defining identity, social relationships, and relationships with the land, as well as being the center for important religious virtues. ${ }^{24}$ The graves are also a way of determining land "tenure" which is based on continuity of settlement, and allows those who can demonstrate the longest connection with the land the strongest say over land-related matters such as rights of access and control over resources. ${ }^{10}$ Because of their inferior position to the state, the Himba's traditional leaders got lawyers, and won the case against the state. Ultimately, the situation caused mistrust between the government and the Himba for misleading them, ignoring them, and for trespassing on their lands without acknowledging their rights. ${ }^{25}$

A prolonged period of colonization and slavery have had a debilitating effect on Sub-Saharan Africa. Throughout the continent, the European colonizers changed ethnic relations by drawing political boundaries, patterns of social organization, and exploiting their natural resources. It has resulted in a huge

\footnotetext{
${ }^{22}$ Andrew Corbett. "A Case Study on the Proposed Epupa Hydropower Dam in Namibia."

Prepared for Thematic Review I.2: Dams, indigenous people and vulnerable ethnic minorities,

December 1999,

${ }^{23} \mathrm{Ibid}$.

${ }^{24}$ Ibid.

${ }^{25}$ Sidney L. Harring. "God Gave us this Land: The OvaHimba, the proposed Epupa Dam, the independent Namibian state, and law and development in Africa." Georgetown International Environmental Law Review, 14(1) (2001): 35-106, accessed December 2, 2015, http:// search.proquest.com/docview/225506935?accountid=10362.
} 
development gap between colonial masters and their former colonies. The colonizers saw no need to invest in development in their colonies unless it served their needs. Because the economy was based on export agriculture, all good arable lands were controlled by wealthy colonial landowners. ${ }^{26}$ The decolonization process was extremely violent but successful because the states gained autonomy. However, gaining independence didn't level the playing field, as they were highly disadvantaged and left in a state of disorder. Governments faced economic, social, and political problems due to limited experience, evidently resulting in corrupt governance. The Epupa Dam proposal is one of many examples of the clash between traditionalism and modernism in the developing world. Furthermore, it demonstrates how hydropolitics and resource management has become a central issue in the developing world. Due to such disparities in economic and political development, foreign intervention is almost always necessary to help accelerate development because the developing countries lack the means to obtain the ends. Unfortunately, the result is an extension of the colonial development relationship, which tends to result in the pushing of a Western agenda on people not yet fully integrated into the global capitalistic system. ${ }^{27}$

Although it's a combination of a prolonged period of colonization, physical geography, corrupt governance, and poor policies, ever-evolving international structures are perpetuating inequity in the global economy. ${ }^{28} \mathrm{~A}$ leading problem in less developed countries (LDCs) is that they are resource rich countries but they are growing much slower than resource scarce countries due to the exploitation of those resources by more developed countries (MDCs) who have a large appetite for resources. They are also extremely vulnerable because we have become such a global economy, making them susceptible to world market prices. Therefore, they must invest in development within their countries, however; they lack the financial ability to do so. In today's world, development is associated with Western, capitalistic style economies.

\footnotetext{
${ }^{26}$ Lester Rowntree et al., Diversity amid globalization: World regions, environment, development (6th Edition). (New York: Pearson, 2014).

${ }^{27}$ A.P. Davis, "Consequences of 'conservation': A Critical look at Namibian Communal Conservancies,” 2011, https://dlc.dlib.indiana.edu/dlc/bitstream/handle/10535/7179/\%20Namibia.pdf?sequence $=1$.

${ }^{28}$ Donald M. Snow. Cases in International Relations (6th Edition). (Upper Saddle River: Prentice Hall, 2014), 222.
} 
International organizations such as the World Bank and the International Monetary Fund (IMF) both assist developing countries in times of economic instability and financial crises by granting loans that are tied to a set of lending conditions. ${ }^{29}$ Although they serve a great purpose, these organizations are far from innocuous as they serve the interests of the core countries in the world. Although they make sizable loans to developing countries as to support sustained economic growth, their Structural Adjustment Programmes have been heavily criticized and received great opposition by the developing world. ${ }^{30}$ These structural adjustment policies have a Western agenda that promotes liberal values in an attempt to democratize these nations. Nicoll (1997) states that "The World Bank, which is not involved in funding the Epupa project, has a long and dismal history of financing large scale development projects in the Third World that are modeled on western conceptions of development, run up huge debt, and do great damage to indigenous peoples and the environment." The large funding of these international organizations by wealthy states also causes a conflict of interest as they can highly influence policies. ${ }^{13}$ Such was the case in South America, which lead to the Bolivarian Revolution in the early 2000's in Venezuela lead by Hugo Chavez, that also influenced leaders in Argentina and Bolivia to rebel against neo-imperialism. It was a leftist socialist movement that was against neocolonialism, a new world order birthed from globalization that promotes global capitalism. ${ }^{31} \mathrm{We}$ also saw a similar rise in land reform from the Zapatistas in Mexico who rose in 1994 in response to the North American Free Trade Agreement (NAFTA), which was detrimental to small farmers in Mexico as it increased corporate influence in agriculture and trade. The Zapatistas were alter-globalization and no longer wanted to be subservient to the Western powers. ${ }^{32}$

In modern times, Indigenous peoples are granted various rights under international law, including a right to their traditional lands, to maintain their cultures, and some measure of local sovereignty to protect those lands

\footnotetext{
${ }^{29}$ Robert Paarlberg. Food politics: What Everyone Needs to Know (2nd Edition). (New York: Oxford University Press, 2013), 209.

${ }^{30}$ Ibid.

${ }^{31}$ Oliver Stone. South of the border. (June 25, 2010) https://www.youtube.com/watch?v=tvjIwVjJsXc.

${ }^{32}$ Ibid.
} 
and cultures. ${ }^{33}$ There have also been new international laws concerned with the displacements of indigenous peoples displaced by the construction of large dams. They state that no government should do harm to poor peoples in order to advance particular schemes of national development. World Bank standards now requires both careful and systematic study of the impact of large dams on local populations, as well as additional standards requiring that forced removals not occur unless the displaced peoples can be relocated without loss of their culture in a position where they are at least as well off economically as they were before relocation..$^{34}$ In 1993, the United Nations Commission on Human Rights adopted a resolution condemning forced evictions as "a gross violation of human rights."35

Globalization is making humanity increasingly interdependent on one another socially, politically, and economically. Although globalization affects everyone, there are vast differences in societies because countries have developed at different rates. The economic disparities between the LDCs and MDCs are emphasized in this new world order, and it is quite evident that not everyone reaps the same benefits from globalization. ${ }^{12}$ One of the defining factors that separates the MDCs from the LDCs are the amount of investments that the government makes in human development. This includes investments in land reform, and often times, indigenous societies are underrepresented and marginalized because of Western ideology of development, and therefore, "economies based on indigenous technologies have been viewed as backward and unproductive because of the distorted concept of patriarchal productivity." ${ }^{36}$

\footnotetext{
${ }^{33}$ Nicoll Ruaridh. "Himba drowning in their desert Eden Namibia's hydro power scheme is endangering an ancient nomadic tribe," The Observer (1997) http://ezproxy.lib.calpoly.edu/ login?url=http://search.proquest.com/docview/250406608?accountid=10362.

${ }^{34}$ Ibid.

${ }^{35}$ Ibid.

${ }^{36}$ A.P. Davis, "Consequences of 'conservation': A Critical look at Namibian Communal Conservancies,” 2011, https://dlc.dlib.indiana.edu/dlc/bitstream/handle/10535/7179/\%20Namibia.pdf?sequence $=1$.
} 